
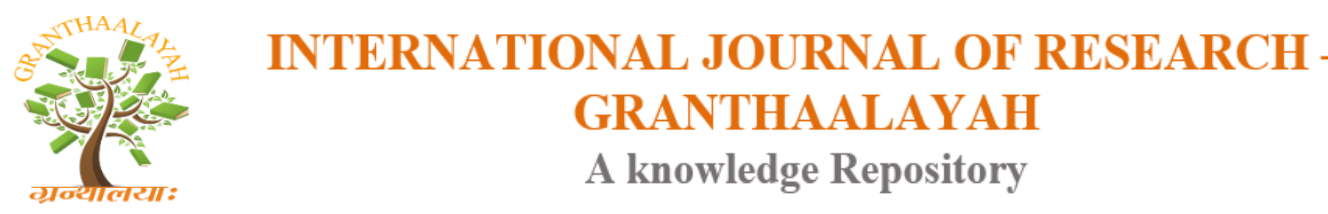

Arts

\title{
NATA SANKIRTANA AND MANIPURI SOCIETY
}

\author{
Dr. M.Thoiba Singh *1 \\ ${ }^{* 1}$ Assistant Professor, Department of Dance \& Music, Manipur University, India
}

\begin{abstract}
The Nata Sankirtana style of singing which was introduced during the reign of Rajarshi Bhagyachandra (1763-1798 A.D.). The great masters and scholars of that period composed and sang the padavali strictly after the Bhagavata tradition and other major Vaishnavite text and based the composition also on the traditional Ragas and Raginis of classical music tradition. Modern research has discovered a lot of regional overtones in the architecture of the particular Ragas and Raginis. The Manipuris call the Nata Sankirtana singing their own and it is clearly a form of collective prayer, a Mahayajna as they call it, lasting for about 5 hours at a stretch with a lot of rituals, movements and rhythmic pattern, strictly after the vaishnavite faith. Nata Sankirtana is a composite version of music, dance and tala; a Sangeet in the true sense of the term. It is also Drishya Kavya, a poem made visible. Nata Sankirtan is a very important aspect in the lives of the people in Manipur. It is because when our end is near, people listen to Hari-naam to relieve us from all the wrong doings that we have done before, so that we die peacefully. After death the family members would take the dead body for the last rites. In the shraddha ceremony, the Nat Sankirtana will start with raga. Before the invocation of the god and prayers start, Pinda-dan cannot be offered. After offering the Pindadan, the owner of the ceremony will have a bath and wear washed clothes. He will then come and offer his respects towards the end of the Sankirtan when Raga Bijay is being performed. The Shraddha ceremony comes to an end with the guardian of the Mandap sending the departed soul to beikuntha dham. In case of any death in a house, Naam Sankirtana plays an important role. In the ten days of mourning or Dashahan, the ritual will start with Naam Sankirtana and other rituals like reading Shrimad Bhagavat Gita will follow. The particular person who mourns, known as the Gira thangba, will only offer Pindadan after the Sankirtana starts. Even in asti sanchai or the ritual of picking up the remains from the grave, Sankirtana is performed along with Parikrama around the Hari mandir. In this manner,for Meitei Vaishnavites living in the society today, Nat Sankirtana Mahayajna was become an indispensable event in the lives of the people since time immemorial. In short, Nata Sankirtana is the only highest karma for the Meitei society. This paper attempts to understand the important role of Nata Sankirtana in Manipuri society.
\end{abstract}

Keywords: Harinam; Ragas; Raginis; Shraddha; Pindadan; Raga Bijay; Mandap; Mahayajna; Meitei; Parikrama; Gira Thangba.

Cite This Article: Dr. M.Thoiba Singh. (2018). "NATA SANKIRTANA AND MANIPURI SOCIETY." International Journal of Research - Granthaalayah, 6(5), 476-480. https://doi.org/10.29121/granthaalayah.v6.i5.2018.1481 


\section{Introduction}

Nata Sankirtana to the followers of Goudiya Vaishnavism is a form of worship. It is considered as a Mahayajna (complete sacrifice).The Vaishnava architects trace its origin to the aesthetics and philosophy of ShrimadBhagavata. In ShrimadBhagavata the only merit in Kaliyuga is Hari Sankirtana (chanting the name of the lord) and through Sankirtana a person can reach his ends and attain moksha. A person in Satyayuga attains mukti through dhyan, in Treta Yuga by yajnas and Dwarpur Yuga through puja and in Kali yuga through Hari Sankirtana. The above dhyan, Puja, Yajana, etc., are all combined or merged in the form of Hari Sankirtana in Kali Yuga to attain salvation. Sri Chaitanya or Lord Gouranga preached the value and importance of Sankirtana to liberate the mortal and make him attain moksha.

The true picture of Manipuri Nata Sankirtana is serving the lord Krishna. Nata Sankirtana was introduced by devotees and priests into the state of Manipur under the aegis of the kings. With the help of rhythm, the lord is invoked, and by using rhythm the lord is worshipped. While worshipping one surrenders himself to the lord and asks for his blessing and this is the inevitable aspect of NataSankirtana. By singing the transcendental love story of Radha Govinda in different rhythms, the devotees have been serving the lord by following the Vedic tradition. In such a manner, worshipping the lord in tune with Vedic norms forms the Nata Sankirtana of Manipur.

In theme and spirit of the NataSankirtana it is the embodiment of bhakti atitsfrom purest.The essence of NataSankirtana is bhakti (devotion). The whole performance is bhakti oriented. It is the depiction of the 'madhurpremrasa'(transcendental love) of Radha Krishna. NataSankirtana is performance-based ritual in which the leelas or plays of lord Krishna are enacted non-realistically. The performance is enacted with subdued acting, dance, music and songs. This abstract performance symbolically represents the merging of both the actors and participants(audience) in the process of ritual performance to another realm where each one of them can identify themselves with the lord.

Thus, Nata Sankirtana is a sacred ritualistic performance. A person can only understand the true essence of Nata Sankirtana only if he is also liberated. The devotion and love enable both the performers and participants to experience Radha Krishna union and transcendental love In later developments, Nata Sankirtana as one of the performing art forms became the foremost means to achieve spiritual goal.

\section{Back Ground}

During the reign of King Kiyamba in 1467-1508 Vishnu temple was set up and people started paying obeisance to Vishnu by offering Sankirtana. After him, his successors, King Charairongba and most of his people in 1697 A.D. took Bhagavat Dikshya and began worshipping Shri Krishna (Madan Mohan) through Hari Sankirtana. In 1709, Maharaj Garibaniwaz founded Drupad Hari Sankirtana which was known as Ariba Sankirtana (Bangdesh Pala) in the rituals of dead ceremonies like Asti and Shraddha. Then in 1763-1798 A.D., under the rule of Maharaj Bhagyachandra, Drupad Hari Sankirtana accompanying Gourchandrika and Goura Bhavi became famous in Manipur. MaharajBhagyachandra was awarded the name Rajarshi and was believed to be the incarnation of Nortom Thakur Mahasoi, an intelligent Shiksha (student) of Loknath 
Goswami of BrajaBrindavan. It was during his period that the temple of Sri Govindajee was installed and started to be worshipped by offering Rasa Kirtan of Lord Krishna.

Drupad Hari Sankirtana was known by the name of Dhrumel HariS ankirtana to the Manipuris from the very beginning. However, Maharaj Bhagyachandra made it so popular that Manipuris knew it as an unique Maha Dhrumel for a long time. Then with the passage of time, following the footsteps of their predecessors, Maharaj Gambhir Singh offered Goura Dhrumel, Maharaj Narasingh offered Nityai Dhrumel and Maharaj Chandrakriti offered Devi Dhrumel. Then the previous Dhrumel Hari Sankirtana ultimately came to be known as Nata Sankirtana keeping in mind the idea of prayer through Sankirtana. And this was how Drupad Sankirtana was divided into two types in Manipur, viz. Ariba Sankirtana (Bangdesh Pala) and NataSankitana (Anouba Pala).

\section{Aspects}

In Nata Sankirtana five aspects namely pung (rhythm/talas), songs, dance, story and rituals are performed at the time of worshipping the lord. The different aspects used in these talas are all not that simple; they are all very ancient, it will be very hard to trace them anywhere in the whole of India. It is clearly understandable with a thorough research into the ways of punglons (drum-beats) as are used in the Sankirtana since long ago. It would be hard to trace any clue even if we scan under the eyes of DesiTalaShastra as is found nowadays elsewhere in India. Perhaps it would never be possible to trace it through this Shastra. Most Pandits (scholars) are of the opinion that such aspects of the Margiyatala have long been ceased to exist from the Indian soil; except a few mentions in the Shastra. It is the pride and prestige of India that such types of Vedic talas found nowhere in India today have long been kept nourished and flourished within the folds of a tiny state like Manipur.

\section{Forms}

There are two forms of Manipuri Sankirtana since the period of MaharajGaribniwas which are as follows:

1) Ariba Sankirtana: It is on record that sankirtana singing took place in Manipur in $15^{\text {th }}$ centuryA.D. during the reign of king Kiyamba of Manipur. But,during the reign of a great Manipuri King Garibniwas(1709-1748 A.D.) who adopted Ramanandi cult, an old school of kirtana singing under the style of Bangadesh or Ariba Pala became popular and is still preserved and practiced at the royal palace and some other centres of Manipur.

2) Nata Sankirtana: Rajarshi Bhagyachandra introduced a new style of kirtana singing known as Nata Sankirtana which found its supreme expression during the reign of king Chandrakirti of Manipur(1850-1886) when the 64 rasa were presented for the first time in 64 sessions spreading over 32 days. The Manipuri musician singing kirtana as called Nataa classical term $n$ Sanskrit, meaning the person who knows the four abhinayas and different types of Natya, gets himself merged in the rasa which he is trying to portray and who appears physically on the stage: a dancer with songs on the lips. 


\section{Functions}

1) NataSankirtana is a very important aspect in the lives of the Manipuri Vaishnavites. It is because when their end is near, people listen to Hari-Naam to relieve them from all the wrong doings that they have done before, so that they die peacefully.

2) After death the family members would take the dead body for the last rites.

3) In the shraddha ceremony, the Nat Sankirtan will start with raga. Before the invocation of the god and prayers start, Pinda- dan cannot be offered.

4) After offering the Pindadan, the owner of the ceremony will have a bath and wear washed clothes. He will then come and offer his respects towards the end of the Sankirtana when Raga Bijay is being performed. The Shraddha ceremony comes to an end with the guardian of the Mandap sending the departed soul to beikuntha dham.

5) In case of any death in a house, Naam Sankirtan plays an important role. In the ten days of mourning or Dashahan, the ritual will start with NaamSankirtana and other rituals like reading Shrimad Bhagavat Gita will follow.

6) Only the specifiedperson who mourns, known as the Girathangba, will offer Pindadan after the Sankirtan starts.

7) Even in astisanchai or the ritual of picking up the remains from the grave, Sankirtana is performed along with Parikrama around the Harimandir.

8) Meiteis have started performing many rites and rituals which they believed are good for themselves. For instance rites related with planting a tulsi or basil plant, rites performed for ponds, temples, houses, death anniversary etc. are all performed along with Sankirtana. Some have it on a small scale and some do it on a large scale according to their choice.

9) On the special day of lord Krishna which is held every year, Nat Sankirtana mahayajna is performed in all the temples within the ShriShriGovindaji shrine and in the BijoyGovinda temple.

10) After the Sankirtana, other performances follow and it closes with Sankirtanbijay. Birthday is celebrated with other performances by men, women and children belonging to different panas thereby serving the lord Krishna and Radha. Even in the temples in different localities such special days are performed with Sankirtana.

11) During holi, men, women and children organizeholikirtan groups and perform in the temples and even in the courtyards of different houses.

12) During the rathyatra festival, young boys and young girls along with older people organize kirtans and perform in temples.

13) Even during Jalakeli and jhulon festivals, young boys and girls along with married women organize kirtan groups to offer to the lord.

14) Within the kirtan many other performances like Krishna leela, rasaleela and gauraleela are also performed following Sankirtana.

\section{Prospects}

Manipuri NataSankirtana has been recognized by the UNESCO in 2013.Sankirtana- the ritual singing, drumming and dancing of Manipur-has been selected for inscription on the Representative List of the UNESCO Intangible Cultural Heritage of Humanity. The decision was taken on December 4, 2013 at the eighth session of the UNESCO Intergovernmental Committee in Baku, Azerbaijan. Following the recognition, the art form will be able to enjoy greater popularity across 
the world, attract scholars and performing artistes from far and wide, and thus the recognition will help in conserving it for the posterity.

Manipuri Classical Dance is closely related to Manipuri Nata Sankirtana as it starts and ends with Nata Sankirtana while being performed.For example in the performance of Rasleela, Nata Sankirtana is performed in the form of Purbaranga, only then Rasleela would follow. The same happens with Gouraleela and Udukhol leela etc.. Therefore, so long as Manipuri Classical Dance like the Ras leela survives,Nata Sankirtana with also survive.

Nowadays Manipuri Nata Sankirtana has become popular in entertainment programmes. For example Pung Cholom (Drum Dance)of Manipur, which is a part of Nata Sankirtana, frequently features in the big festivals even at the international level. This kind of exposure and nurturing will help in the survival and enrichment of this art form provided we do take care not to allow it to become too much commercial.

\section{Conclusion}

Lastly, it is notable that NataSankirtana which is an art form transmitted from generation to generation through traditional school of guru-sishyaparampara is now institutionalized, along with the traditional school. And it becomes the fourth Indian art form recognized by the UNESCOas an Intangible Cultural Heritage. So it is hopeful that this ritualistic art form, associated with the cultural life of the Manipuris from birth to death will thrive to live on as part of Indian cultural Heritage despite the onslaught of mass consumerist culture.

\section{Profile}

Dr. MeikamThoiba Singh (b.1966). At present serving as Assistant Professor at the Department of Dance \& music, Manipur University. He got his Ph. D. in pung from Manipur University in 2004. Also a Post Graduate in Pung from the Jawaharlal Nehru Manipur Dance Akademy Imphal, and A high Grade Manipuri Music Artist of AIR,Imphal, he has authored four books on Meitei Pung. As a performing artiste he has visited USSR, Japan, North Korea, Thailand, Philippine, Bangladedh and USA. He has presented many papers in the National and International seminars $\&$ conferences on traditional Manipuri Art \& Culture.

\section{References}

[1] Sanakhya EbotombiHaorokcham, Nata Sankirtana,2010

[2] Elangbam Nilakanta Singh, Aspects of Indian Culture,1982

[3] Aribam Chitreshwar Sharma, NataSankirtana Amasung Masiga Mari Leinabasing, 2012

[4] Dr. M. Kirti Singh, Religious Developments in Manipur in the $18^{\text {th }} \& 19^{\text {th }}$ centuries, 1980.

[5] N.Tombi Singh,Manipur and the Mainstream,1975.

*Corresponding author.

E-mail address: m_thoibasingh@yahoo.com 